\title{
A HERMENEUTICS OF IGNATIAN MYSTIQUE: CREATION IN CHRIST
}

Uma hermenêutica da mística inaciana: a criação em Cristo

Walter F. Salles *

\begin{abstract}
It has become commonplace among scholars of Ignatian mysticism to establish a dialogue between the theme of creation and modern or postmodern ecological sensitivity in order to update the practice of the Spiritual Exercises of St. Ignatius of Loyola. The trajectory of this essay leads the reader through some aspects of the debate that this attempt to update has raised. The dual objective of this reflection is to show that the theme of creation in Ignatian mystique is inseparable from the idea of creation in Christ, and that the neglect of Christology structuring Ignatian mystic of Spiritual Exercises often leads to practices that no longer deserve the adjective of Christian neither Ignatian. This article is a descriptive and interpretative investigation based on a bibliographic study that is divided into four parts: the specification of the terms hermeneutic and mystical, the context of the Spiritual Exercises' text, its elaboration, and finally the contemplation of the life of Christ as Creator.
\end{abstract}

KEYWORDS: Creation. Christ. Hermeneutics. Mystic.

RESUMO: Tornou-se lugar comum entre os estudiosos da mística inaciana estabelecer um diálogo entre o tema da criação e a moderna ou pós-moderna sensibilidade ecológica a fim de atualizar a prática dos Exercícios Espirituais de Santo Inácio de Loyola. O duplo objetivo dessa reflexão é mostrar que o tema da criação na mística inaciana é indissociável da ideia da criação em Cristo, e que o esquecer-se da cristologia que dá modo e ordem à mística inaciana dos Exercícios Espirituais conduz frequentemente a práticas que não merecem mais a adjetiva-

\footnotetext{
* Society for Ricoeur Studies, University of Pittsburgh, Pittsburgh, Pennsylvania, United States. Available in: $<$ http://www.ricoeursociety.org/>.
} 
ção de cristã e tampouco de inaciana. Esse artigo é uma investigação descritiva e interpretativa com base em um estudo de cunho bibliográfico que está dividida em quatro partes: a especificação dos termos hermenêutica e mística, o contexto do texto dos Exercícios Espirituais, a sua elaboração, e finalmente a contemplação da vida de Cristo como Criador.

PALAVRAS CHAVES: Criação. Cristo. Hermenêutica. Mística.

\section{Introduction}

Some people have been trying since several years to establish a relaOtionship between Ignatian mystique and ecology. Sometimes, in my opinion, it is a forced thing that is particularly strange when one considers that Ignatian practice of Spiritual Exercises has Christian tradition as its birthplace. This strangeness is what motivated me to search the Ignatian mystique and try to understand how the theme of creation can help the reader and interpreter of the Spiritual Exercises to decipher life itself through Ignatius words, based on a given fundamental part of Christian faith: creation in Christ.

The hypothesis that conducts my reflection is the existence of an Ignatian vocabulary that privileges the image of God as Creator and Lord. Far from being just a numerical data, it is notorious that Ignatius, who was so careful when choosing words, uses the word Creator fifteen times in the text of the Spiritual Exercises. This shows that Creation is one of the structuring axes of the four weeks as Ignatius conceived them. My aim is to emphasize that, for Ignatian mysticism, this creation is always creation in Christ and to show that forgetting Christian originality often leads to a practice that sets aside fundamental elements of both the Christian tradition and the Ignatian mysticism, since it is founded by the Tradition.

\section{Some Preambles}

The beginning stage of this reflection requires an introductory observation on two aspects that structure the sentence that gives the title to this essay: hermeneutics and Ignatian mystique. I start with the second aspect and take as reference the considerations made by Father Ulpiano Vazquez sj (VÁZQUEZ, 2005, p. 15-18). Ignatian mystique can be summed up in two sentences: "Contemplative in action", and "Loving God in all things and all things in God". The first phrase is not from Saint Ignatius of Loyola, but from the Jesuit priest Jerônimo Nadal, who used this expression to 
refer to Ignatius ${ }^{1}$. When Father Nadal spoke of being contemplative in action, he referred to the act of seeing God's action or work in Creation. In other words, this emphasis means seeing that who actually acts or works in the world, in all things, is God Himself, and the human being, as a creature, can collaborate with the divine work ${ }^{2}$. The second sentence is from Ignatius of Loyola himself who affirms the impossibility for a spiritualized and Christian person to believe in a God without world and to live in a world without God. More: to pretend to love people without God or to love God without loving anyone. Ignatius calls our attention, therefore, to a double temptation: wanting to flee the world to find God in an illusory spiritual paradise or despairing about not finding God in the world, in History. Taken together, the two expressions, from Nadal and Ignatius, say that Ignatian mystique points to a balance, to the ability to see God at work in the world and to love Him in created things and, still, to love created things in God. This is the way of being a mystic in the action that takes place in the world created by God.

With regard to the term hermeneutics applied to Ignatian mystique, once more, I use an observation made by Father Ulpiano Vázquez sj that takes us back to a story narrated by another Jesuit, the Portuguese father Antônio Vieira (VÁZQUEZ, 1997, p. 203-213). In this story, Father Vieira argues in favor of the impossibility of reproducing the image of Saint Ignatius. Laying on his deathbed, Ignatius begins to be painted by an artist who sees the dying man without being seen by him. The painter's intent is to appropriate an image of Ignatius of Loyola in a unique and unmistakable way before death made this definitely impossible. However, this attempt proved to be unattainable because Ignatius' face was transformed every time the painter, after making a sketch, looked again at the Saint's face. The figure of Ignatius, changing at every moment, is lost and transformed in the next moment.

Vieira's baroque creativity tells us that the look of the painter and of all those who try to fix the original, unreachable figure of Saint Ignatius is doomed to failure (VIEIRA, 1959, p. 423-424). For Vieira, the best portrait of Ignatius of Loyola is in the one portrayed by himself in the Spiritual Exercises. Thus, as Father Ulpiano warns, in the place of the painting, Vieira places a book, and in the place of the painter, he places a reader. The impossible portrait cedes place to the hermeneutics of a text. "The

\footnotetext{
${ }^{1}$ Father Jerônimo Nadal, Spanish, born in Majorca, was a trusted man of Inácio of Loyola. Ignatius commissioned him to promulgate the Constitutions of the Society of Jesus by the Jesuit houses in several countries in Europe.

${ }^{2}$ Although the expression "Contemplative in action" is not literally by Saint Ignatius, it brings us to the text of the Spiritual Exercises, more specifically to the so-called Contemplation to Achieve Love, when it is suggested to those who do the Spiritual Exercises "to consider how God works and labors for me in all creatures upon the face of the earth, that is, He conducts Himself as one who labors. Thus, in the heavens, the elements, the plants, the fruits, the cattle, etc., He gives being, conserves them, confers life and sensation etc" (Spir. Ex., n. 236).
} 
book, the text, is the place of the true encounter between Ignatius disappeared forever and the reader or readers who seek him" (VÁZQUEZ, 1997, p. 206). Ignatian mystique therefore reaches us today as a book and as such needs to be interpreted.

A consequence of this passage from the impossible picture to the text is the fact that Ignatian mystique must be deciphered in Ignatius' own writing, that is, in the text that helps the reader or the one who receives the Spiritual Exercises to decipher his own life in the mirror of the words. The hermeneutics of the Ignatian text occurs in the spiritual conversation that takes place between the reader and the text, and this conversation is partly motivated by Ignatius' conviction that he can contemplate God in all created things, which "does not exclude this divine creature that the word is. To see God in all things is also to see him in the true, necessary and respectful word that reveals God" (KOLVENBACH, 1981, p. 486). Writing was, therefore, for Ignatius, the possibility of meeting God and finding himself in Him, as his spiritual diary testifies: "Rereading this immediately and considering it well written, I feel a new devotion, not without tears in my eyes. Then, as I remember these graces received, a new devotion" (Spir. Diary, n.9).

Thus, what is usually called Ignatian mystique has its primary source in the Spiritual Exercises of St. Ignatius of Loyola. Based on the etymology of the word "text" and the four weeks of the Spiritual Exercises as the warps that support and give dynamism to the mystagogy of the Exercises ${ }^{3}$, it is possible to say that among the various plots that weave Ignatius' text, the idea of God as Creator and the human being as a creature is undoubtedly a central idea. However, as Father Ulpiano observes, it is necessary to warn the reader that, by assuming the theme of creation as the guiding thread of the hermeneutics that I propose in the text of the Spiritual Exercises, I do not intend to turn Ignatius of Loyola into an ecologist or to make Ignatian mystique dialogue with a science such as ecology today. This does not exempt us, however, from stating that Ignatian mystique may provide a conversation "with the man or woman who lives in a world in which ecological problems have become vital for the survival of humanity" (VÁZQUEZ, 1997, p. 208).

In any case, it is important to remember that the creation in Ignatian perspective is of a different order, it is Christian, and as such it means adherence to a person who is confessed as the Incarnation of God: Jesus Christ. This is because, as the Second Vatican Council recalls, "[i]n real-

\footnotetext{
${ }^{3}$ The term mystagogy literally means initiation into the mysteries. In early Christianity, this term designated the explanation of initiation rites in the Christian life, especially baptism and the Eucharist. I use the term mystagogy here to designate the movement by which those who receive Spiritual Exercises are led to the Mysteries of God through the mysteries of the life of Christ our Lord.
} 
ity it is only in the mystery of the Word made flesh that the mystery of humanity truly becomes clear" (GS, n. 22). In this sense, the experience of the Spiritual Exercises is a particular Christian experience that provides the grammar of the language that allows those who go through the four weeks to narrate their own experience with God. This is possible because there is a minimum of continuity between Ignatius' experience and ours, both grounded in the Christian faith ${ }^{4}$. Furthermore, the experience of the Spiritual Exercises supposes faith in the action of the Holy Spirit who, as he did with Ignatius, leads us today in the ecclesial experience of the Exercises. Forgetting this Christological perspective, this ontological solidarity of the Incarnation, the constitutive relationship between the life of Jesus and ours, can reduce the theology of Creation to a metaphysical explanation of reality (PALÁCIO, 2013, p. 176) or, still, simply identify creation with Pachamama, Mother-Earth or Gaia.

\section{The "pre-text" of the Exercises" text: traces of a Tradition}

As Christian Tradition teaches, faith in the God Creator is one of the fundamental features of the Christian faith, as attested by several passages in the Sacred Scriptures. For Christian tradition, God's creative act is always creation in Christ (Eph 1,3-14; Col 1,15-20). It is in Christ and through Him that God created, creates and recreates continuously everything. The first article of the so-called Symbol of the Apostles, for example, clearly states "I believe in God, the Father Almighty, Creator of heaven and earth". The way in which God is named in the Apostles' Creed or Symbol is only possible by recognizing and welcoming the presence of the One who created everything. The Tradition expressed in the articles of the Creed rests, therefore, on the unity between Creation, Redemption and Sanctification ${ }^{5}$. This profession of faith (I believe in God the Father ... I believe in Jesus Christ ... I believe in the Holy Spirit) does not, however, reduce Christianity to a pure humanism, since the reference to God the Father who reveals himself in his Son by the power of the Holy Spirit is fundamental ${ }^{6}$.

\footnotetext{
${ }^{4}$ Three of the four weeks that conducts the practice of Spiritual Exercises are dedicated to the contemplation of the life of Jesus Christ according to the New Testament tradition. With rare exceptions, such as the appearance of the risen Christ to Our Lady (n. 218; 299) and Joseph of Arimathea (n. 310).

${ }^{5}$ BOUILLARD, Henri. "Le nom de Dieu dans le Credo". In: CASTELLI, E. (org.), L'analyse du langage Théologique. Le nom de Dieu. Paris: Montaigne, 1969. CAMELOT, P-T. "Le symbole des Apôtres: origines, développement, signification", Lumière et Vie, v. 55, p. 61-79, 1952. DE LUBAC, H. La foi chrétienne. Essais sur la structure du symbole des Apôtres. Paris: Éditions Aubier-Montaigne, 1969.

${ }^{6}$ On this reference that underlies the Christian faith and is expressed in sacramental cult, seen CHAUVET, L.-M. Symbole et Sacrement. Une relecture sacramentelle de l'existence chrétienne. Paris: Les Éditions du Cerf, 2011.
} 
The Ignatian experience is situated in this unitary perspective of the Christian confession of faith. Ignatius of Loyola was unaware, for example, of the division that the modern exegetical and theological tradition has come to call the rupture between the historical Jesus and the Christ of faith (PALÁCIO, 2013, p. 85). With regard to the theology that structures the practice of Spiritual Exercises, this division is in fact the negation of the Incarnation itself and, as it is known, this was a heresy that threatened the unity of Christian faith in its beginnings. The spontaneous identification between the historical Jesus and the Risen Christ allowed Ignatius to propose this colloquy: "Imagine Christ our Lord present before you upon the cross, and begin to speak with him, asking how it is that though He is the Creator, He has stooped to become man, and to pass from eternal life to death here in time, that thus He might die for our sins"7 (Spir. Ex., n. 53). It is a conversation with someone alive, with the Risen Christ, so Ignatius tell us "to imagine" instead of "to see" Christ on the cross. This distinction in the use of the verbs to imagine and to see is fundamental because it refers directly to the scholastic theology studied by Ignatius, which helps us to understand that saying "I believe in Jesus Christ ..." is to confess that the Jesus (historical) is the Christ (Risen).

The union between Jesus and Christ is what underlies Ignatius' obsession with being sure about the correct position of Jesus' feet on the rock from which the Risen Christ ascended to heaven (Auto, n. 47). What for modern thought can be configured as a pious banality, for Ignatian mysticism has a profound theological significance as it carries an immense respect for the humanity of Jesus, always united to his divinity. In addition, the sequence of the Autobiography account narrates a fundamental fact. Upon being pulled from Mount Olivete ${ }^{8}$ by the guards, Ignatius is taken back to the Franciscan convent where the other pilgrims already were. While being reappointed, Ignatius claims to have received from "Our Lord great consolation: as he seemed to see Christ above him" (Auto, n. 48). This vision and the impossibility of staying in Jerusalem give to Ignatius of Loyola the certainty that wherever he, Ignatius, was, Jesus Christ would be with him. The whole world becomes Jerusalem or a place to serve the Creator of all things, thanks to the everlasting presence of the Risen Christ.

In my view, the lack of perception of this unity, expressed in the confession of faith "I believe in Jesus Christ", is the fundamental modern difficulty regarding the exercises for contemplating the mysteries of the life of Christ, once it proposes Lord's internal knowledge, by suffering with the Christ who suffers for me and therefore experiencing the joy of the Risen Christ (Spir. Ex., n. 104, 103, 221). It means to savor the unity between life, death

\footnotetext{
${ }^{7}$ For English text, I use PUHL, Louis J. The Spiritual Exercises of St. Ignatius. Chicago: Loyola University Press, 1951.

${ }^{8}$ Place of the Ascension of Jesus Christ according to an ancient tradition.
} 
and resurrection that underlies Christian faith. Something often overlooked by many Christians who easily adhere to certain religious fads that have little or nothing of Christian. It is scandalous to see how in the name of interreligious dialogue, for example, the confession of faith in Jesus Christ is easily replaced (or at best relativized, which in practice is the same) by characters from other religions (PALÁCIO, 2013, p. 113). We are facing what many scholars call secularization of the Christian faith, that is, believing in Jesus Christ, adhering to His person, is no longer evident or fundamental in our contemporary secularized society ${ }^{9}$. Strictly speaking, God is no longer an assumption of modern or postmodern society or, at most, believing in God has become an option among so many others ${ }^{10}$. It is from this relativization that Christians leave aside what the Symbol of the Apostles teaches us, that is, to confess with faith and heart the faith in Jesus Christ (Acts 2,36; Eph 2,11). And in doing so, they often reduce the mystery of Christ to a simple example of a universal moral (CHAUVET, 2011, p. 311). They also transform the contemplation of the mysteries of the life of Christ Our Lord, proposed by Saint Ignatius, in the appropriation of a moral conduct that, strictly speaking, can be replaced by another non-Christian one.

\section{The textualization of a mystical experience}

The slow elaboration of the text of the Spiritual Exercises rests on a double experience: Ignatius' own itinerary and his practice of helping people to seek and find God's will (RAHNER, 1989, p. 31-57). Through a very careful choice of words, Ignatius communicates the experience of a familiarity with God, with the Creator who bursts into his life and who is the origin of all the events narrated (KOLVENBACH, 1981, p. 482). The Creation had a fundamental role in the life of Ignatius as he himself narrates it in an excerpt from his Autobiography, on the occasion of his convalescence in the Castle of Loyola:

The greatest consolation he had discovered then was to contemplate the sky and the stars. He did it many times and for a long time, because with this he felt a great effort in himself to serve our Lord. He often thought about his purpose, wishing to be healed completely, to set out on his way. (Auto, n. 11)

In contemplating creation, Ignatius contemplated God's creative and redeeming love. He saw the action of God in the world and this aroused

\footnotetext{
${ }^{9}$ See the three volumes of Joseph RATZINGER (Bento XVI). Ser cristão na era neopagã; Campinas: Ecclesiae, 2014, 2015 e 2016. Texts originally published in the magazine "30 giorni nella Chiesa e nel mondo".

${ }^{10}$ See TAYLOR, Charles. A Secular Age. Cambridge: Harvard University Press, 2018.
} 
his desire to serve God in Creation, especially the desire to help others or to help souls, as he used to express himself. Here there is already a clear difference between Ignatius' experience and a certain contemporary ecological sensibility, that is, the contemplation of nature led Ignatius to come out of himself to serve Our Lord Jesus Christ helping others people. Ignatius' attitude distances him from modern humanism that only looks at Creation without looking up at God, and also responds to the temptation of a spiritualism that does nothing more than look up at the sky. Ignatius had his feet on the ground and his eyes (and, why not, his heart) turned to $\operatorname{God}^{11}$.

Ignatius found in the contemplation of the mysteries of the life of Jesus Christ the passage that unites the "above" and the "below", we could say that he saw in Christ the "ladder" that unites heaven and earth, as announced in Jacob's dream (John 1,51; Gen 28, 10-17). This experience of Ignatius, little by little, led him to the "ease of finding God", seeing "Christ as the sun" (Auto, n. 99). This experience of Ignatius may be better understood from the desire for a search for guidance, for a reference point that helps giving meaning to human existence (VÁZQUEZ, 2001). This desire for orientation or direction is summed up in the objective of the Spiritual Exercises, that is, "the conquest of self and the regulation of one's life in such a way that no decision is made under the influence of any inordinate attachment" (Spir. Ex., n. 21).

Etymologically, to give meaning to life is to find the way, the direction, the reference points that allow the orientation, that make it possible to put order in the walk. From Ignatius' experience, we can say that "theo-graphy" means the possibility of life guidance based on the marks, on the points of reference, that God leaves in the life of each of His creatures, and mystagogy, in turn, becomes the meaning of these divine marks (VÁZQUEZ, 2001, p. 11).

Ignatian mystagogy is based on the certainty that God marks people's lives, on the belief that the Creator acts with and within His creatures (Spir. Ex., n. 15; 330). Theographic experiences cannot be understood by themselves. These experiences are similar to stained glass that does not make sense if in isolated pieces just as when together, but without sunlight, cannot be seen. The stained glass remains, therefore, incomprehensible. These experiences gain meaning only when read and interpreted from the life of Jesus Christ. Christ as the sun (Auto, n.29; 99) that allowed Ignatius to orient himself towards the theographic time and space is, in fact, the foundation of all Christian life (RAHNER, 1964, p. 251). The God Creator

\footnotetext{
${ }^{11}$ As an example of this synthesis between "above" and "below", between Creator and created things, see the beginning of the letter addressed by Ignatius to Francisco de Borja (Rome, September 15, 1555).
} 
through the mysteries of Jesus' life leads the way of all those who left themselves to be led by His Spirit.

\section{The Contemplation of the Creator's Life}

The history of the practice of Spiritual Exercises over more than four centuries reveals the emergence of several trends regarding the interpretation of Ignatius' text (CUSSON, 1993, p. 4-34). Here, in a very specific perspective, in dialogue with a certain contemporary mentality with an ecological bias, I restrict myself to a path that favors the Christian experience of God and that Ignatius used to call the encounter between the Creator and the creature (Spir. Ex., n.5). In this experience, typical of Ignatian mystique, exterior time and space are at the service of spiritual experience, and time is divided by Ignatius into four weeks which, as we know, do not necessarily obey the seven-day chronology (Spir. Ex., n.4). From the course of these four weeks, the human being sees himself created, saved and called to follow Christ by serving others. In other words, it is about meditation and contemplation of the History of Salvation, which is configured in a creative experience of true life that is set in motion by the theography and mystagogy of the Spiritual Exercises (Spir. Ex., n.139; 1 Tim. 6,9).

Ignatius of Loyola's text evidently has a style of language and mental representations that refer to the first half of the 16th century and to certain characteristics of Ignatius himself. Therefore, Ignatius' world, his cultural and political space, is no longer ours. But if we take into account the indications presented by the French philosopher Paul Ricoeur regarding the interpretation of a text (RICOEUR, 1969, p. 322), we see that it is not a matter of looking for the author, in this specific case, looking for Ignatius behind the text, but it is a matter of deciphering one's own life through of words of Spiritual Exercises' text. However, this decipherment carries a double risk: that of pure archeological character and anachronism. The first would mean nothing more than a sterile return to the structure of Ignatius' text. For example, when one sees only where the word Creator is used. The second often leads to a vain attempt to update Ignatian text by arbitrarily imposing on it recent theological discourses and some ecological sensitivities.

From this observation or considering this double danger, it is important to remember that in Ignatian mysticism the horizon of the life of Jesus Christ is the epigenetic horizon from which human being has the possibility of having his own life recreated (VÁZQUEZ, 2001, p. 25-28). This horizon does not make Jesus a model to be followed, since one model can always be replaced by another. In the case of Christian life, as Saint Paul says to the Corinthians, that is, "[f]or other foundation can anyone lay than that which is laid, which is Jesus Christ" (1 Cor 3,11). It is in this sense that 
we can understand that the First Week of Spiritual Exercises deals with the experience of a new creation through forgiveness and always starting from a first creation, both first and new creations as the creation in Christ. Irenaeus of Lyon, by means of a symbolic correspondence, affirms that Christ died on the sixth day of the week, the same day of the creation of Adam: "To recapitulate that day in Himself, the Lord then comes to his Passion on the eve of the Sabbath, which is the sixth day of creation, in which man was modeled, thus granting to man through his Passion the second model made from death" (IRÉNÉE DE LYON, 1984, p. 637-638). Redemption is thus a new creation in Irenaeus' theological perspective ${ }^{12}$. For Ignatius, this novelty gains visibility in the contemplation of the mysteries of Christ's life and then opens up to the perspective of following Christ in the world.

For this reason, the contemplations of the Incarnate Creator's life are preceded by the exercise of the "Call of the Eternal King" (Spir. Ex., n. 91-100) that serves as the foundation of the contemplations that extend from the Incarnation to the Resurrection. Following Christ, responding to his call, is the concrete way to open up to a new life, recreated by the presence of the Risen Christ in the world, and to order his own history based on the story of Jesus. It is in this maternal language of Christian tradition, deeply Christological (Eph 2,15; 4,24; Col 1,15; 3,9-11), that Ignatius relies on speaking of Jesus Christ as Creator and Lord (Eph 2,15; 4,24; Col 1,15; 3,9-11). Jesus, in his condition of the Risen is who enables the creation of a new life of which He is the principle and foundation. In Ignatius' Christological language, this new creation consists of appropriating the intention of Christ our Lord, in which one asks for the grace of an intimate knowledge of our Lord in order love Him more and follow Him more closely. This only can be known and felt in the movement out of oneself through love and following the Eternal King, the Creator incarnate, dead and risen, under His standard (Spir. Ex., n.135, 104 e 136-147). In Ignatian language, this follow-up is experienced from the horizon of things created and divinely oriented towards God, as the preparatory prayer for the First Week, which will be the same for the other weeks, synthesizes well (Spir. Ex., n.46).

These contemplation exercises as conceived by Ignatius of Loyola are part of the so-called Devotio moderna (ROTSAERT, 1982, p.19-60) ${ }^{13}$. They are partly the answer to the question that Ignatius himself was asking: how

\footnotetext{
${ }^{12}$ For some theologians, Ignatius is heir to the patristic conception of creation in Christ, as can be seen in the divine title "Creator and Lord" used several times in the text of the Spiritual Exercises. In this regard see CODINA, Victor. "Claves para una hermenéutica de los Ejercicios". Manresa - Espiritualidad Ignaciana, Madrid, v. 186, p. 61-69, 1976. For a synthetic view of the Theology studied by Ignatius, see the second chapter of the work MELLONI, Javier. La mistagogía de los Ejercícios, p.71-103.

${ }^{13}$ It is a spiritual movement, born in the Netherlands at the end of the 14th century, having developed throughout the 15th century, whose aim was to nourish the inner life through various forms of meditation, unlike a certain speculative mystique of the centuries XIII and XIV.
} 
will Jesus Christ appear to me? (Auto, n.21 and 37). It is in this desire to see Jesus that Ignatian contemplations are inscribed over the course of three weeks of the Spiritual Exercises, and in these exercises the imagination helps to understand how the Creator makes himself audible and visible, as well as to welcome the gaze of whom is the epiphany of God's icon (KOLVENBACH, 1987, p.9-24). The mystagogical process of contemplations thus becomes a process of Christification since human life finds in the mysteries of the life of Christ our Lord a horizon of conformity from which a new creature emerges from of the old man and walking towards fullness in Christ (Gal 4,19; Eph 4,17-19). It is, in Ignatius' words, "the true life that teaches the supreme and true captain" (Spir. Ex., n. 139) ${ }^{14}$, and, in the words of Saint Paul, the mystery which has been hidden in God from ages and now has been revealed to us in Jesus Christ (Col 1,26-27).

Thus, the risen Christ, who little by little pulled Ignatius from the paralyzing fixation of seeing only in Jerusalem the place to serve the Creator and Lord (Auto, n. 35-53), moves us today to have a renewed view on creation. In the same way as for Ignatius Jerusalem transforms itself in the whole world, it's our matter to day to direct our view on the world and to serve God in all created things. And this renewed view on creation is made possible by the action of the Holy Spirit who moves us from our ancient condition towards the condition of a new creature in Christ (BEAUCHAMP, 1992, p.169). If Saint Paul speaks of the action of the Holy Spirit through the gift of discernment and the effects of joy (1Cor 12,10-11; Rom 14,17; Gal 5,22; 1 Tim 1,6), Ignatius tells us to "look at the office of consoler that Christ Our Lord brings, comparing it with the way in which friends tend to console each other" (Spir. Ex., n. 224) ${ }^{15}$. For the Christian faith and Ignatian mysticism, the Holy Spirit, the Paraclete or the Consoling, is also the protagonist together with the Father and the Son (1 Jn 2,20; 27; 2 Cor 3, 3 17; Gal 4,6), protagonism that brings about the new creation in Jesus Christ in us.

\footnotetext{
${ }^{14}$ Several translations, frequently including the Portuguese one, uses "chief" in place of "captain". However, I prefer to keep the term captain, as it appears in the original Spanish (capitán). I consider this term more faithful to Ignatius of Loyola's linguistic style. In my opinion, Ignatius retained this distinction to make a clear difference between the warlord or chief who is Lucifer, the deadly enemy of our human nature, and Christ Our Lord who is the true captain (Spiritual Exercises, n.138). In French, for example, this distinction is marked by the contrast between Capitaine (Christ) and chef (Lucifer); in English, we find Commander-in-Chief or Commander (Christ) and "chief" (Lucifer). The term chief is not used singly to refer to Christ. For the Spanish text, see the BAC edition (Biblioteca de Autores Cristianos), 1991, p.254.

${ }^{15}$ In the original Spanish: "Mirar el officio de consolar, que Cristo nuestro Señor trae, y comparando cómo unos amigos suelen consolar a otros". Ignatius writes in his text that Christ brings the office of consolation and not that He exercises directly such office. This distinction is particularly important because it allows us to refer to the Holy Spirit in the context of the Spiritual Exercises. In fact, to Ignatius, the Holy Spirit is the presence of God the Father and the Risen Christ in our lives. Consolation is a Trinity's action.
} 


\section{Conclusion}

Ignatian mysticism, therefore, is configured by a Christification made possible by the contemplative exit of oneself into the time and space of Jesus Christ Our Lord, moved by the desire for the Lord's inner knowledge to love and follow Him (Spir. Ex., n. 104). Contemplations are more than just remembering the life of Jesus Christ through imagination. They are communion with Him, or the fusion of horizons of two lives: that of Jesus with that of those who receive Spiritual Exercises. Those who contemplate are affected (their affections are touched) by the one who is contemplated, so Ignatian mystique is both contemplative and practical, which differs from a strictly speculative Christology, and from mere personal and affective satisfaction. And in this fusion, human life does not cease to be renewed, recreated, by the movement or passage from one horizon to another, from one life to another, from our life to the life of Christ, and vice versa. It is this movement or passage that allowed Saint Paul to say "It is no longer I who lives, but Christ lives in me" (Gl 2,20). It is in this sense that Ignatian contemplations are at the service of the new creation, in Christ. A novelty that must be the principle and foundation of the Christian identity, the appropriation of the Christian life, which must be mystical and Christological. Only in this way is the dialogue between Ignatian mystique and modern or postmodern ecology made possible.

\section{Abbreviations}

Auto = The Autobiography of St. Ignatius Loyola

GS $=$ Gaudium et spes

Spir. Diary $=$ The Spiritual Diary of St. Ignatius Loyola

Spir. Ex. = Spiritual Exercises

\section{References}

BEAUCHAMP, P. Le récit, la lettre et le corps. Paris: Seuil, 1992.

CONCÍLIO VATICANO II. Compêndio do Vaticano II: constituições, decretos e declarações. 29.ed. Coordenação de Frederico Vier. Petrópolis: Vozes, 2000.

CHAUVET, L.-M., Symbole et Sacrement. Une relecture sacramentelle de l'existence chrétienne. Paris: Cerf, 2011.

CUSSON, G. C. Petite histoire de l'interprétation des Exercices - écoles et tendances. Cahier de Spiritualité Ignatienne, Roma, n. 33, p. 15-34, 1993.

IGNATIUS, Saint The Spiritual Exercises. Chicago: Loyola University Press, 1950.

IGNACE DE LOYOLA. Exercices Spirituels. Paris: Desclée de Brouwer, 1986. 
IGNACIO DE LOYLA, Saint. Obras. Madrid: BAC, 1991.

INÁCIO DE LOYOLA. Autobiografia. São Paulo: Loyola, 1991.

INÁCIO DE LOYOLA, Santo. Exercícios Espirituais. Porto Alegre,1966.

IRÉNÉE DE LYON. Contre les hérésies. Dénonciation et réfutation de la gnose au nom du menteur. Paris: Cerf, 1984. p. 636-638.

KOLVENBACH, P.-H. Images et imagination dans les Exercices Spirituels. Centrum Ignatianum Spiritualitatis, Roma, n. 54, p. 9-24, 1987.

KOLVENBACH, P.-H. Le poids de mots dans la prière chez saint Ignace. Christus, Paris, n. 1688, p. 480-493, 1995.

MELLONI, J. La mistagogía de los Ejercícios. Bilbao-Santander: Mensajero - Sal Terrae, 2001

PALÁCIO, C. Mistérios de Cristo. Mistério do cristão. São Paulo: Loyola, 2013. (Leituras \& Releituras, n.18).

RAHNER, H. La genèse des Exercices. Paris: Desclée de Brouwer, 1989.

RICOEUR, P. Le conflit des interprétations. Essai d'herméneutique. Paris: Seuil, 1969.

ROTSAERT, M. Ignace de Loyola et les renouveaux spirituels en Castille au début du XVIe siècle. Rome: Centrum Ignatianum Spiritualitatis, 1982.

VÁZQUEZ, U. Mistogogía ignaciana y ecología como compasión. Manresa - Espiritualidad Ignaciana, v.70, p. 203-213, 1997.

VÁZQUEZ, U. A orientação espiritual: mistagogia e teografia. São Paulo: Loyola, 2001. (Leituras \& releituras, 3).

VÁZQUEZ, U. A Mística Inaciana. Itaici - Revista de Espiritualidade Inaciana, São Paulo, v. 62, p.15-18, dez., 2005.

VIEIRA, A. Sermões III. Porto: Lello \& Irmão, 1959.

Article submitted on May, 13, 2020 and accepted on Aug. 14, 2020.

Walter F. Salles has a doctoral degree in Sciences of Religion; he has a postdoctoral degree from both University of Pittsburgh - USA (2018) and Pontifical Catholic University of Rio de Janeiro - Brazil (2010). He is a member of the Iberoamerican Association of Ricoeur Studies (ASIER) and of the Society for Ricoeur Studies (SRS). He is a Freelancer Translator (Loyola Editions). Orcid.org/0000-0002-9125-3518. E-mail: waltersalles04@gmail.com

Address: Rua Marco Grigol, n.200, casa 18.

Chácara Belvedere

13085-360 Campinas - SP 